\title{
Chapter 8 \\ Social Policy in the EU and Turkey: the Limits of Europeanisation
}

\author{
Dimitris Tsarouhas
}

\section{Introduction}

Social policy has received little attention during the course of Turkey's accession negotiations, and most of the debate regarding Turkey's EU future has concentrated on political and security-related aspects instead. Yet it would be wrong to dismiss social policy as an unimportant policy area of little significance to Turkey's EU aspirations.

Social policy matters at the EU level, not only because of the effects of the economic crisis on peoples' incomes and jobs, but also because the EU level has by now replaced the national one as the most effective platform on which to design and implement social policy (Teague 2000). Furthermore, Turkey is a rapidly growing economy whose expected transition from a middle- to high-income country poses a new set of challenges regarding its socio-economic cohesion and the avoidance of gross inequities harmful to the realisation of the country's potential (Tsarouhas 2010). Social policy is in that sense of growing significance for Turkey, and its evolution will affect the country's socio-economic model for decades to come. Whether a more prosperous Turkey will remain a deeply unequal Turkey, with all the consequences that such inequality besets upon the educational, social and economic development of the country, is a vitally important policy question.

In what follows, I begin with a brief exposé on the Europeanisation literature and subsequently discuss the concept with reference to candidate countries. The next section links the theoretical discussion to EU social policy and briefly looks at the evolution of the latter, as well as the extent to which social policy is subject to an Europeanisation trend for EU states. In the next part Turkish social policy is discussed in more length by use of two yardsticks: the hypothesised Europeanisation effect on candidate countries' policies, and the effect of 'soft' policy harmonisation, i.e. cognitive Europeanisation, on social policy structures at the national level of social policy-making, design and implementation. The conclusion summarises the main findings.

The chapter's main argument points to a weak Europeanisation effect on Turkish social policy reform. At best, 'Europe' is used as a legitimisation device for policies conceived and designed at the national level and with domestic political priorities in mind. Although the end result is an approximation of some 
of Turkey's social policy structures to those prevalent in some EU states, this tends to be more the result of the policy design chosen and less of policy transfer mechanisms at work. Accounting for the limited effect of Europeanisation is the weak development of EU social policy, the demonstrated weaknesses of the soft coordination approach in introducing substantial policy change (as exemplified in the unsatisfactory progress Turkey has made towards signing up to the Joint Inclusion Memorandum) and the related neglect of social policy as a major item in pre-accession negotiations. In that sense the Turkish record on social policy reveals interesting similarities with the pre-accession record of Central and Eastern European countries (CEECs) and their policy trajectory prior to EU accession.

Before proceeding, some definitional clarifications are in order. European social policy can denote social policy arrangements in EU (European Union) member states, or refer to initiatives taken and policies formulated at the EU level by member states in cooperation with other institutions. In this chapter I adopt the second definition when referring to European social policy. Moreover, Turkey has a 'Social Policies' Ministry, yet this is part of a bigger Ministry that includes 'family policies' (aile politikasi). The Ministry does not deal with social policy conventionally defined, as this is the primary responsibility of the Ministry for Labour and Social Security (MLSS), focusing instead on issues such as domestic violence, assisting people with special needs and so on.

\section{Europeanisation}

\section{Origins and Usage}

Since Europeanisation is used with increasing frequency in the academic literature (Mair 2004), albeit in an often loose manner, it is important to start with some basic analytical distinctions.

Europeanisation is distinct from European integration. While the former acknowledges the two-way process of interaction between the EU and national level, the latter is about member state adjustment to obligations stemming from Brussels-made commitments. Moreover, one should distinguish between Europeanisation and harmonisation, the latter being the effect of EU rules and policies across a range of state activities and affecting both institutions and policies (Page 2003). It is more useful to ask whether Europeanisation brings about policy convergence or divergence, considering that it is by now empirically shown that Europeanisation does not impact all states and/or policy actors in the same way across the Union, and it rarely brings about harmonisation in policy outcomes (Radaelli and Pasquier 2008: 39).

Europeanisation was first used in the 1990s (Ladrech 1994), and has grown ever since to encompass not only member states but also candidates and even potential candidate countries. It first came into being as a result of the inadequacy of classic European integration theories to analyse, explain and account for the 
impact of the EU on member states (Bache and Jordan 2006: 18). One of the best definitions of Europeanisation is provided by Radaelli (2000: 4), who sees Europeanisation as

Processes of a) construction, b) diffusion and c) institutionalization of formal and informal rules, procedures, policy paradigms, styles 'ways of doing things' and shared beliefs and norms which are first defined and consolidated in the making of EU decisions and then incorporated in the logic of domestic discourse, identities, political structures and public policies.

The richness of the above definition captures the formal and informal character that Europeanisation entails, and allows one to go beyond purely mechanistic readings of Europeanisation as transposition or rule conformity and see it as a complex process of socialisation into new ways of acting.

\section{What - and How - Europeanisation?}

The traditional approach to Europeanisation looked at its 'top-down' effects, the extent that is to which EU pressures have led to changes in domestic policy structures - or indeed have failed to do so. The 'goodness of fit' explanation was then used to explain the resulting empirical data, arguing that both the EU-member state match but also institutional and structural features of the polity ought to be considered when assessing the resulting fit or misfit (Börzel and Risse 2003). This approach allowed for the introduction of the new institutionalist literature on the Europeanisation debate by offering the opportunity to use sociological or rationally grounded institutionalist approaches to measure the effect of Europeanisation on national policy settings.

The alternative, 'bottom-up' approach uses the EU level as intermediate; it starts and finishes with the domestic level, as it tracks the EU effect on domestic politics and policies, including political actors (Vink and Graziano 2008: 9). Seeking to answer the question of the real (rather than assumed) EU effect on domestic policies, the bottom-up approach is well-placed to employ methodologically sound approaches, such as process-tracing, to come up with the right explanandum in case of policy change.

A key challenge in the Europeanisation literature, as the discussion above implies, is to identify its mechanisms, that is, the ways in which it has a clearly discernible and measurable impact on policies and politics. Knill (2001) offers three: institutional compliance, changing domestic opportunity structures and framing beliefs and expectations.

Institutional compliance refers to explicit European policies that prescribe a specific institutional model that has to be introduced. This offers member states limited discretion on how to implement change, and can therefore be seen as representing 'hard' Europeanisation. Changing domestic opportunity structures describes instances where European policies alter the distribution of power and 
resources between domestic actors and as a result allow for institutional change to occur. The final mechanism, framing domestic beliefs and expectations, suggests that the EU aspires to restructuring the cognitive input of actors by driving them towards a new mental understanding of change that will, in turn, be the result of their socialisation process. This last mechanism stands in contrast to the first as it is based on 'soft law' mechanisms of domestic change, and can be linked to the policy framing debate (Radaelli and Schmidt 2004) on the use of policy language justifying particular policy choices as more appropriate than others. It has also been termed cognitive Europeanisation (Guillén and Alvarez 2004).

\section{Europeanisation and Candidate Countries}

Schimmelfenning and Sedelmeier (2005) have discussed Europeanisation in candidate countries, nicely linking two debates relevant to the discussion of Europeanisation mechanisms introduced above. First, the pressure exerted by Brussels on aspiring member states to assume the formal/legal acquis communautarre and implement it in their national legal and administrative structures (hard mechanism); second, the pressure by the EU on candidate countries to internalise its set of normative codes of conduct and 'appropriate' policy behaviour, a much less formal yet not necessarily less powerful form of pressure (soft mechanism) (Bache and Jordan 2006: 32, see also Bulmer and Radaelli 2004: 2).

Two different parts of the enlargement literature have looked, first, at the process of conditionality and rule adoption by member states and, second, the way that Europeanisation affects state structures and policies. A third strand (Schimmelfennig and Sedelmeier 2008: 89) has examined the ways in which the process of accession has affected individual policy areas, such as transport, the environment or social policy.

The extent to which rules have been adopted and patterns of policy-making have changed is subject to multiple factors, but a general rule of thumb has emerged with time and is particularly applicable to Turkey. First, EU rule adoption by candidates is heavily (and positively) correlated to the credibility of the commitment made by the Union to (eventually) accept the candidate. Second, with respect to individual policy areas, a pattern emerges whereby it is the significance that the Union places on that particular policy area, rather than veto players or domestic costs associated with policy change, that account for the degree of compliance with EU rules. Finally, Europeanisation understood as domestic change motivated by the influence exerted by the EU resulting from its 'carrot-and-stick' capability offered by accession conditionality is much more likely to occur for candidates compared to countries the EU is merely associated with (see Heritier 2005).

Domestic policy change should be seen as the result of an interactive process. On the one hand international institutions and actors press for policy change through direct or indirect means based on their policy leverage; at the same time governments operate within the constraints of their political environment, administrative capacities and ideological orientation (Guillén and Pallier 2003). 
Furthermore, it is important to differentiate between the types and extent of influence that the EU process can have on candidate countries' policies. The EU can be a model in the sense of transposing into national law and custom EU practices; it can be a template, in terms of offering a way of doing things without necessarily mimicking EU practices; and it can also be a legitimising device, offering legitimacy to policy-makers' choices and priorities and allowing them to make discursive use of 'Europe' so as to promote their preferred policy choices (on this issue see Vink and Graziano 2008).

The experience of previous candidate countries on social policy varies. Guillén and Alvarez (2004) suggest that Spain, a catching-up country in the 1980s whose social policy structures were weakly developed, first expanded and then rationalised its welfare state under EU influence. More important than copying into Spanish law the EU social policy acquis, Spanish policy-makers were affected by the Union in that the latter offered a template of reform and a means to concentrate on the kind of society desired in the future (Guillén and Alvarez 2004).

Both Spain and Portugal have been influenced by EU membership in terms of making a qualitative as well as quantitative (social protection expenditure) leap forward in their welfare arrangements. Geographical proximity was combined with domestic pressures for change to enhance social protection. Attaining 'European levels' of social protection has been essential in driving reform forward, as has been the EU template in constructing a universal healthcare service, especially in the case of Portugal (Guillén et al. 2001).

Yet the CEE experience suggests that the EU factor can play out differently too. Frege (2002) suggests that the EU has played a secondary role to the international financial institutions in social policy restructuring in Hungary, and has been happy to go along with 'American-style liberalisation' of social policy. In contrast to Southern Europe, where social policy expansion was encouraged by the EU, retrenchment and 'Americanisation' rather than Europeanisation occurred in CEE. This does not have to be the case in Turkey (Manning 2007: 498), but is closely connected to the nature and salience of social policy in the EU.

\section{EU Social Policy}

European social policy is underpinned by an oxymoron: on the one hand, the idea that social policy at Community level should be strengthened, and that the common challenges faced by EU states battling high levels of social exclusion and poverty necessitate a form of Europeanised response, is very popular (Begg and Berghman 2002: 180). The economic crisis and its socially disruptive consequences reinforce the need for more concerted action on the social policy front at supranational level.

On the other hand, however, there is strong resistance among many member states to the idea of a Europeanised social policy and the uploading of policy competences to the Union, as these national-level competences have been negotiated over a long time, are associated with the nation state and its obligation to serve citizens' welfare, 
and have thus acquired a nearly untouchable status. Moreover, EU social policy has always had a meaning different from the one attributed to it at national level. Rather than centred on income redistribution, services provision and social protection, EU social policy has traditionally meant labour market regulation, anti-discrimination legislation and regions-based income support. In recent years, social policy has gone beyond labour market regulation and anti-discrimination rules to embrace a more comprehensive understanding of social policy. EU action is nowadays a mix of legislation, regulation and policy coordination.

The latter has been increasingly adopted in an attempt to address problems common to member states without removing the latter's competences. This process has with time led to new debates as to whether some sort of latent or 'creeping' Europeanisation may be on the cards, especially since 'soft' methods of policy coordination, primarily the Open Method of Coordination (OMC), were adopted in policy areas such as pensions, healthcare and social exclusion. According to an optimistic reading, this enhanced the scope of EU activism in social policy beyond the labour market and emerged in parallel to the Union's adoption of a citizenshipbased perspective in its understanding of social policy (Threlfall 2007).

Until the 1980s and with the exception of the Social Action Programme (Daly 2007: 2), social policy received little attention within the Community. At a time when welfare capitalism was on the ascendancy across Europe, the notion of a European social policy framework was of secondary importance to the construction of a common market. After all, the belief that market excesses should be corrected at the national level was part of a national settlement and cross-party consensus on the role of the state in economic policy. For the founders of the Union, social policy thus remained a national concern (Tsoukalis 1993: 151). This was despite the fact that the Rome Treaty had in places explicitly addressed social policy issues, going as far as envisaging social systems' harmonisation at some point in the future. However, the social policy acquis was largely confined to employment regulation and anti-discrimination laws, implemented with varying degrees of success in the member states.

Commission President (1985-95) Jacques Delors played a decisive role in giving a push to Europe's Social Dimension. Delors made use of the new opportunities offered by the Single European Act, and especially Article 118a that foresaw the possibility of majority voting on health and safety issues, thus bypassing national vetoes. This increased the acquis on health and safety issues over time and broadened the scope of employee protection. In addition, Delors sought to give a powerful say to the social partners on employment regulation and social issues by initiating the European Social Dialogue (Hantrais 1995). Today, agreements reached between the two sides go some way towards offering a solid regulatory layer over employment conditions and include agreements (which in some cases have become Directives following TEU provisions) on parental leave, part-time work, flexi-work, telework, stress at work and violence at work. Other achievements during that era are the 1989 Fundamental Social Rights of Workers (that excluded the UK) and the Social Protocol annexed to the Maastricht Treaty. Both documents marked progress 
in the social policy field (O'Connor 2005: 347), yet their minimalist and strictly voluntary character narrowed the room for manoeuvre available to the pro-social policy coalition. The definition of social policy remained circumscribed and the headline goal of EMU overshadowed 'Social Europe'.

At the beginning of the 1990s, the EU was still busy seeking to establish new legislative norms in the field of social policy and promote institution-building in order to respond to popular pressure for a stronger social dimension (Tsarouhas 2007: 33). Although some member states wished to see social policy emerge as an autonomous actor in EU policy-making, it was quite clear that a move beyond employment policy was not seen as particularly necessary. One pertinent example is the refusal by the Council to adopt the 4th Poverty Programme, which was premised on a serious funding increase compared to the previous one (Larsen and Taylor-Gooby 2004: 185). During that time, the realisation that institutionbuilding was becoming more difficult led to the adoption of a policy coordination approach. The concept of social exclusion was introduced as persistently high unemployment rates marginalised large parts of the population and an attempt to introduce a more holistic approach to social issues began.

The 1997 Amsterdam Treaty was a step forward in that it made social exclusion policies subject to QMV voting. Three years later, the Nice European Council set particular objectives for the Union in combating both poverty and social exclusion and set out to do so by mobilising all relevant actors, facilitating employment participation, assisting the most vulnerable and preventing the risk of exclusion (Daly 2006: 466). This constituted a major development, to the extent that poverty now became an integral part of Union policy, at least in rhetorical terms, in contrast to the limited and under-funded anti-poverty programmes of the past. What is more, social policy was explicitly recognised as a productive factor as well as an instrument to tackle inequalities and social exclusion (Larsen and Taylor-Gooby 2004: 188).

More significant yet was the incorporation of social exclusion in the EU's flagship Lisbon Agenda in the year 2000. 'Lisbon I' was premised on the assumption of a virtuous circle guiding the relationship between jobs, growth and (preventing) social exclusion. Using clearly defined objectives and based on common guidelines, the EU made a leap forward in its perspective. It ceased conceiving social policy in labour market terms only and broadened its scope insofar as it spelled out a comprehensive approach marrying employment opportunities with 'rights, resources, goods, services, helping the most vulnerable [and] preventing social exclusion' (Daly 2007: 5). This was a social rights approach that conferred a new dynamic to social policy. To implement the new approach, the EU relied on the Open Method of Coordination (OMC), a system previously tried out in economic and employment policy.

In the year 2000 it was decided that poverty and social exclusion policies would be subject to the OMC, a 'soft law' approach to social policy based on numerical and qualitative targets debated and agreed upon by member states and with the Commission playing a coordinative and regulatory role. Essentially this stands for fixing EU Guidelines and setting implementation timetables; translating 
these into policy initiatives based on national peculiarities and institutional traditions; setting benchmarks to assess best practice and follow these up by use of periodic monitoring, evaluation and peer review. The goal would be to facilitate policy learning (Zeitlin and Pochet 2005) by incentivising countries to imitate best practice followed elsewhere without evoking the stick of legal sanctions in case of failure to do so.

Eighteen indicators to measure progress and reduce social exclusion were first agreed upon at the 2001 Laeken Summit, and elaborate definitions of poverty were developed. Action Plans were formulated by member states but the process appeared to be running out of steam following the midterm review of the Lisbon Strategy and the publication of the 2004 Kok Report. Its unflattering conclusions on EU progress towards meeting the Lisbon objectives (High Level Group 2004) led to a fundamental change in approach. Social exclusion was merged with the pensions and healthcare OMCs (both had been initiated in 2004) and the term itself was replaced with 'active social inclusion', making the previously loosened link with labour market activation stronger yet again. In addition, efficiency has become a dominant theme of the new policy approach replacing the previous emphasis on prevention as the best way to tackle social exclusion (Daly 2007: 7). The EU response to the economic crisis suggests that social policy is unlikely to become a more salient policy area in the near future, despite the fact that the June 2010 EU Council meeting agreed a headline goal of lifting 20 million Europeans out of poverty by 2020 (European Commission 2011b).

Soft law in general and the OMC in particular are reliant upon cognitive Europeanisation understood as 'the shaping and reshaping of the perception of and attitudes towards social problems and the way to tackle them' (Guillén and Alvarez 2004: 286). In addition to the implementation of the acquis and its transposition into national law, this is an alternative way to judge the effect of the EU on member states and candidate countries' policies. It relies less on hard evidence and more on discursive changes related to the design and conceptualisation as much as the actual legislative changes introduced by states. In the field of the 'Social OMC', candidate countries are expected to sign on to the 'Joint Memorandum on Social Protection and Social Inclusion'. Following that, their progress in aligning their social policy practices with the EU equivalent is monitored through conferences and implementation reports. Turkey has yet to complete the process of signing up to the Joint Inclusion Memorandum.

\section{Social Policy in Turkey}

\section{An Overview}

To analyse the extent to which EU candidacy and its alleged Europeanisation effect has influenced Turkish social policy, I begin with a brief overview of its main characteristics. 
First, the Turkish state devotes a low percentage of public expenditure to social protection. Organisation for Economic Cooperation and Development (OECD) figures point to an increase in such expenditure from 7.6 per cent in 1990 to approximately 11 per cent in 2009 (Tsarouhas and Bölükbaşı 2007, OECD 2009). This remains substantially below the OECD-27 average of 22.4 per cent. Connected to low expenditure is the fact that social policy in Turkey essentially amounts to a combined system of health and pension coverage, as well as stateprovided education. The combined nature of health and social security is important for expenditure too. Health expenditure per capita in different regions in Turkey is linked to the coverage of social security schemes. As the social security coverage ratio increases, so does health expenditure per capita (Yilmaz and Emil 2010: 58). According to the Turkish Statistical Agency's data, 13 per cent of the population receive a regular pension, 2 per cent unemployment benefit and 3 per cent are in receipt of child benefit (see Aybars and Tsarouhas 2010: 757).

Low expenditure is combined with real and persistent risks of social exclusion and poverty. The percentage of people at risk of poverty after social transfers stands at 26.5 per cent, the highest among all EU states and candidate countries (Eurostat 2010). Although Turkey is a dynamic and vibrant economy with high growth potential, its socio-economic status suggests the need for major improvements. The latest UNDP Human Development Index, a comparative measure of life expectancy, life standards, education and literacy ranks Turkey 83rd among 169 nations. The country is now in the 'High Human Development' category - but only just, as the next level (medium human development) begins with countries ranked 86 and below. The worst performing EU state, Bulgaria, occupies the 58th spot, EU candidates Croatia and Macedonia rank 51st and 71st respectively. More importantly, perhaps, in medium- and low-income countries, the correlation between economic growth and improvements in health and education is weak (UNDP 2010: 4).

Social policy in Turkey has traditionally been very fragmented. The initial steps towards the establishment of social security took place in the 1940s and sought to provide coverage for workers and employees. In a country with a large agricultural sector and rural population, this left a large share of the population uncovered. Most Turkish citizens were residing outside urban centres and were thus left out of all social security schemes (Boratav and Özuğurlu 2006). Over time, steps have been made to integrate different forms of coverage.

Access to services varies greatly and the primary determinant of access has traditionally been employment status. In that sense, the Turkish system is similar to the Bismarckian, employment-based and status-determining system, whereby civil servants enjoy conditions of access and benefit types of higher quality compared to white-collar workers in the private sector, blue-collar employees and agricultural labourers. Yet as will be discussed later, recent reforms aim at improving some forms of welfare access for the most vulnerable, easing on gross inequities and unifying service provision.

Additionally, Turkey has traditionally lacked a societal constituency pressing for a 'social state', despite the fact that such a proclamation was written into 
the country's constitutional charter in 1961. This, combined with a statist tradition dating from the Ottoman era and a strongly centralised state that has not decentralised health or education decisions to the municipal level means that social policy is a top-down affair with little input from other actors. On the other hand, recent years have witnessed a growing trend towards private medical and pension insurance. Turkey's economic dynamism combined with a strongly liberal political economy framework has driven a large part of the population to private providers for such coverage (Adar 2007: 168).

A final point by way of introducing the Turkish social policy landscape is the significance of informal mechanisms of welfare transfer that often replace absent state-run services or institutions. The family is a central unit of social care as well as income support and sits in tandem with clientelistic practices aiming to bypass an occasionally stifling bureaucracy (Buğra and Keyder 2006).

\section{Social Policy Reform in Turkey}

In recent years, the Turkish social policy landscape has undergone rapid transformation. Accounting for this transformation goes through tracing the process of change, centring on the two policy areas that constitute the essence of Turkish social protection: pensions and healthcare.

\section{Social Security}

Starting from the 1980s, Turkey's political economy had acquired a strong promarket, liberal bias that viewed social security as a heavy burden on state finances and the main culprit for repeated fiscal crises (Tsarouhas and Bölükbaşı 2007: 15). Meanwhile, the system was heavily imbalanced, as the ratio of pensioners to active contributors was rapidly deteriorating, and the system's corporatist character was increasingly detached from the reality of the Turkish labour market dominated by informality and low female employment rates (Buğra and Keyder 2006, Aybars and Tsarouhas 2010). In addition, populist politics during the 1980s and 1990s led to an effective abolishment of the minimum retirement age.

Although worthwhile reform proposals were made by a host of institutions, it was the World Bank's package of recommendations that eventually led to reform in 1999. The package included both short-term measures to make social security viable and long-term changes to transform the administrative and organisational structures of social security (Aybars and Tsarouhas 2010: 753). The 1999 reform first increased the retirement age for both sexes, increased the minimum contribution period and raised the premium ceilings (OECD 2006).

Further and more drastic reforms have been implemented in recent years, in line with World Bank recommendations and backed by strong IMF support. A package of laws that cleared legal hurdles by 2008 has established a new administrative structure whereby the Social Security Institution (Sosyal Güvenlik Kurumu, SGK) 
is now the umbrella institution covering the funds for private sector employees (Sosyal Sigorta Kurumu, SSK), civil servants (Emekli Sandiği, EK) and the selfemployed (Băg-Kur). A single pension system has thus been created. Secondly, the state now assumes the responsibility of making contributions to the social security system to ensure its future viability, a first in Turkey, and unifies all social security institutions under the Ministry for Labour and Social Security. Third, further changes in the eligibility criteria, minimum contribution and retirement age have been set. They include a long transition period, yet the end point is a drastic rise in retirement age, reaching 65 years for men and women by 2048 and rising to 68 years by 2075 (Aybars and Tsarouhas 2010). Fourth, and as will be discussed in more detail below, the changes also entail an attempt towards universal healthcare provision.

Criticism has been raised against the reforms, the most significant of which relates to 'the marketisation of services and encouragement for the private sector to collaborate in a public-private mix of service provision' (Yakut-Çakar 2007: 124). This is likely to deepen inequalities, the argument goes, in a country where inequality is already very high (Boratav and Özuğurlu 2006). Moreover, it has been argued that the reforms do little to address the underlying problem of informal employment and these employees' entry to the formal economy. Still, the reforms make social security more viable in the long run and increase efficiency in what used to be a loosely coordinated system.

The international financial institutions have been active in the reform process through reports, press releases and public statements pushing for change and seeking to build consensus around the blueprints of their own proposals. The recent changes have been very much in line with their preferences, and their ability to influence this debate came in the wake of a long-term structural adjustment programme signed with Turkey in the wake of the latter's 2001 financial crisis. To use only one example, when the changes on social security structures were announced in 2006 the IMF announced its willingness to release a large loan to Turkey (Adar 2007: 167). Moreover, the World Bank's Country Partnership Strategy with Turkey 2008-11 declared the implementation of the social security reform a 'key priority' (World Bank 2008: 11), and announced support for the implementation of the Health Transformation programme (see section below) through 'analysis, advice and financing' (World Bank 2008: ii).

\section{Health Care}

Healthcare constitutes the second major item of the Turkish welfare state. The country spends approximately 6 per cent of its GDP on healthcare, with more than 70 per cent stemming from public sources (Ministry of Health 2009). Though its mortality, morbidity and life expectancy rates have all improved drastically over the last decade, Turkey still compares badly on these data with EU-27 countries. What is more, a lack of physicians, nurses and primary care units makes changes in the healthcare system all the more important. 
Healthcare reform had been on the cards for decades. Yet political instability stemming from successive short-lived coalition governments combined with periodic economic crises had led to reform neglect of a fragmented healthcare system that only covered about two-thirds of the population. For the rest, who are particularly poor and socially vulnerable, a Green Card scheme was created in 1992. Beneficiaries are decided by district heads (muhtar) and the main criterion is an income of less than one-third of the minimum wage. The system did not achieve its main objective of leading to universal coverage (World Bank 2005).

In 2003 a law was passed to discontinue fragmentation in healthcare provision (divided as it was between the Health Ministry, university hospitals, military hospitals and the private sector) and create a more equitable system of healthcare delivery. Successive laws have been enacted ever since to fulfil this framework objective. Since 2005 Green Card holders are entitled to outpatient care and SSK insures have access to all public hospitals and pharmacies. Since 2006, the pharmaceuticals' list extends to all insurers under the various funds, including Green Card holders.

Since 2007, benefits across the health insurance systems have been harmonised for people insured under all major funds, ceasing the practice of privileged access for civil servants and their dependants, and restricted access to the rest (Resmi Gazete 2008). The new General Health Law is universal and covers all residents of Turkey. It foresees automatic coverage for all people under the age of 18. According to the new system, the state contributes to social insurance (as do employers and employees), while tax revenues are used to cover the healthcare needs of those who are not insured. Other provisions of the law encourage private health insurance by allowing private providers to make user charges between 30-70 per cent more than SGK (Y1ldirım and Y1ldirım 2011: 190), and introduce a referral system so as to encourage the (underdeveloped) primary healthcare services through family practitioners.

The new package of health laws is potentially driving the healthcare sector towards universalism. In deciding to opt for obligatory coverage for all under the age of 18, Turkey is following on the steps of other South European states who have introduced universalism in the recent past (Aybars and Tsarouhas 2010). Combined with the fact that Turkey suffers from high child poverty rates, this change is potentially transformative of healthcare delivery and services in the country, particularly as healthcare expenditure as a percentage of GDP continues to grow, reaching 5.6 per cent in 2010 (European Commission 2011c).

\section{Turkish Reforms and the Role of the EU}

How extensive has the EU role been then in the conceptualisation and implementation of these far-reaching reforms? To answer one ought to consider the earlier discussion on different degrees of leverage that the EU maintains, as well as the fact that no candidate country is under direct pressure to conform to a particular social security 
or healthcare system as there is only a limited acquis on these policy areas. It is thus significant to look for the EU factor by means of cognitive Europeanisation and the extent to which Turkish policy-makers have used EU devices, standards, data and policy frameworks to argue their case for reform.

Findings suggest that government ministers and parliamentarians have evoked EU comparisons and periodically sought to legitimise reforms by creating linkages between the social security situation in the EU and Turkey. In the process, some use of EU standards and member states' practices becomes evident. Parliamentary minutes from the relevant debate in 2006 reveal how the then Labour Minister argued the case for reform by comparing social security expenditure in Turkey and 'European countries' (Turkish Parliament 2006a). The government party's spokesperson on that law argued that the reform was an attempt to bring Turkish standards into line with those prevalent in the EU (Turkish Parliament 2006b). Later, the Labour Minister explicitly asserted that the new law was part of Turkey's alignment with the EU acquis, as well as the government's economic programme (Çelik cited in Duyulmuş 2009: 21).

Furthermore, EU norms and standards were not purely an act of rhetorical legitimisation. There was some attempt at lesson-drawing where EU requirements acted as a template for changes in the Turkish system. In 2008 Parliament discussed the revised version of the social security law following some annulments introduced by the Constitutional Court the year before. One of them pertained to principles on pay increase for actual periods of service for certain occupations (Duyulmuş 2009). The Labour Minister drew attention to a study that was later presented by an assigned official. The study, conducted by the General Directorate for Insurance, examined EU regulations on pay increase for different occupations groups and suggested a Turkish regulation in line with those standards (Turkish Parliament 2008).

Duyulmuş (2009) has argued that the use of EU norms, standards and practices as legitimising practices for reform by policy-makers was frequently used in 2005 and 2006. Ever since, however, a steady decline in such usage is observable, and the social security reform issue becomes framed more and more in terms of domestic considerations and needs. Importantly, the lessening of references to the EU and its member states coincides with the cooling of EU-Turkey relations and the growing perception in Turkey of insurmountable obstacles on the way towards full membership.

The fact that the accession process is technically going on, and that the social policy and employment chapter can be opened once opening benchmarks have been met, means that a certain dynamic is still evident. To illustrate, the number of EU experts in the MLSS has gone up from 25 in 2006 to 60 in 2010 (MLSS 2011). This is in line with higher budgetary allocations on the part of the EU to Turkey as part of the Instrument for Pre-accession Assistance (IPA) launched in 2007. Moreover, it is noteworthy that since 2009 the MLSS Activity reports include as part of the Ministry's core aims and objectives the alignment with EU standards and practices in the field of employment protection, social exclusion and social dialogue. The list 
of aims and objectives did not include such references in the years 2006 until 2008, the period when EU-Turkey relations were less troublesome.

Despite such progress, opening the social policy and employment chapter has not been possible, as Turkish standards still fall short of the acquis and corresponding ILO Conventions. The constitutional amendments approved by a referendum in 2010 marked an important step forward. Restrictions on civil servants' right to collective bargaining and collective agreements were lifted, the ban on membership in more than one trade union was abolished and the right to have more than one agreement covering the workplace was granted. However, the strike ban on civil servants remained in place. Moreover, the labour rights granted by these changes have yet to be enacted, as the social partners continue to disagree on a new threshold for collective bargaining and the right to organise at workplace level (European Commission 2011c: 78).

With regard to the emphasis paid by Turkish policy-makers on efficiency and budgetary savings in both healthcare and social security this sits well with the EU's policy on welfare state modernisation. This is evident in terms of its positive evaluation of the social security reform in terms of fiscal savings (Verbeken 2007). It can also be explained by the fact that the EU's adopted reform angle, emphasising cuts over expansion and efficiency over distributional effects, is in accordance with the Turkish government's approach to social welfare.

When it comes to healthcare, the legislation that Turkey ought to transpose relates to substance abuse, mental health, blood tissues and cells as well as a general financing framework (chapter 28). Progress on that field has been steady (European Commission 2007), and negotiations opened in December 2007. The 2009 progress report released by the Ministry for Health included the Ministry's objectives for the 2009-13 period, in which carrying out the 'European Union harmonization/accession process' was included as part of its strategic aims and objectives (Ministry of Health 2009: 118). Yet this comprehensive document on the Health Transformation Programme makes scant reference to the EU accession process and opts for references/benchmarks by use of World Health Organisation standards instead.

\section{Conclusion}

Assessing the effect of Europeanisation on Turkey is a difficult task due to the country's uncertain EU trajectory and the continued turbulence on its way towards full membership. The credibility of EU commitment to this particular enlargement round is in doubt, unlike that of the recent CEE enlargement, and Turkish progress towards meeting the political criteria for membership has been unsatisfactory.

In the area of social policy things become still more complicated for two main reasons. Firstly, unlike the acquis on labour law, social dialogue and employment protection, the acquis on social protection is very limited and so the direct EU leverage over Turkey and the rest of the candidate countries is rather minimal. EU 
social policy, reinvigorated for a brief period in the early 2000s, remains low on the Union's policy priorities and plays a marginal role in pre-accession negotiations. While Turkey is part of the IPA and has been receiving an increasing amount of EU funds in recent years, the amounts committed to social policy through the 4th IPA Component (Human Resources Development) remain insignificant compared to regional policy or institution-building. To illustrate, in the 2009-11 period and out of a total budget of $€ 2.2$ billion, the Human Resources Development component of IPA amounts to $€ 196$ million with only 20 per cent falling under 'social inclusion' (European Commission 2009). When it comes to the policy coordination element, candidate countries become actively part of the 'Social OMC' following the completion of their 'Memorandum on Social Protection and Social Inclusion'. Turkey has yet to finalise this process and therefore EU leverage over the country's social policies is very low.

Secondly, Turkey's starting point on social policy issues, from a qualitative and quantitative point of view, differs greatly from the EU-15 pattern and resembles the situation in CEE states prior to accession. That means that lesson-drawing from the EU-15 becomes more complicated and this is important due to Turkey's inclination to be compared with EU-15 states rather than with its closer neighbours in CEE.

With regard to the empirical data discussed above, Turkey, unlike many of its EU counterparts, has undertaken bold reforms in the areas of social security and healthcare. In the process of doing so and certainly in the early years of implementation (approximately between 2003 and 2006), there is a weak yet discernible impact of 'cognitive Europeanisation' acting as a legitimising device. Policy-makers tried to argue the case for reform on grounds of their own, efficiencyoriented policy priorities but sought to frame reform in terms of convergence with European norms and standards. Over time this becomes weaker although the MLSS has recently adopted EU terminology on social exclusion.

In terms of the direction of social policy reform, the ongoing attempt to universalise healthcare coverage in Turkey has a lot in common with similar experiences in countries like Portugal. Both Portugal and Spain had used EU membership as a cognitive guide to reform their welfare structures towards greater equity in healthcare and an increase in social expenditure. The Turkish Health Transformation plan and increased social expenditure point to a very interesting similarity. It should be stressed, however, that the Turkish reform plans also entail a bigger role for the private sector in service provision, increased use of user charges to access public healthcare and performance-related pay. All of these sit well with the Turkish government's political orientation and point to the high salience of domestic factors in shaping welfare reform.

Finally, the data of the Turkish case also point to some similarities with the welfare reform pattern followed by CEE states in the 1990s, in particular with regard to the highly influential role of the international financial institutions. The World Bank and the IMF have been key actors in shaping the contours of social security and healthcare reform in Turkey through finance, project initiation, implementation, expert advice and support. Their role has been more direct and 
more visible than that of the EU. Turkey's long-established cooperation with both of those institutions, the 2001 crisis and the congruence in reform outlook between the international financial institutions and successive Turkish governments are the key factors accounting for their ability to influence Turkish social policy over a number of years.

\section{References}

Adar, S. 2007. Turkey: reform in social security. Journal of European Social Policy, 17(2), 167-8.

Aybars, A.I. and Tsarouhas, D. 2010. Straddling two continents: social policy and welfare politics in Turkey. Social Policy \& Administration, 44(6), 746-63.

Bache, I. and Jordan, A. 2006. Europeanisation and domestic change, in The Europeanisation of British Politics, edited by I. Bache and A. Jordan. London: Palgrave, 17-33.

Begg, I. and Berghman, J. 2002. Introduction: EU social (exclusion) policy revisited? Journal of European Social Policy, 12(3), 179-94.

Boratav, K. and Özuğurlu, M. 2006. Social policies and distributional dynamics in Turkey, 1923-2002, in Social Policy in the Middle East, edited by M. Karshenas and V.M. Moghadam. Basingstoke: Palgrave Macmillan, 156-89.

Börzel, T. and Risse, T. 2003. Conceptualizing the domestic impact of Europe, in The Politics of Europeanisation, edited by K. Featherstone and C. Radaelli. Oxford: Oxford University Press, 57-80.

Buğra, A. and Keyder, Ç. 2006. The Turkish welfare regime in transformation. Journal of European Social Policy, 16(3), 211-28.

Bulmer, S. and Radaelli, C. 2004. The Europeanisation of public policy, in MemberStates and the European Union, edited by C. Lequesne and S. Bulmer. Oxford: Oxford University Press, 338-59.

Daly, M. 2006. EU social policy after Lisbon. Journal of Common Market Studies, 44(3), 461-81.

Daly, M. 2007. Whither EU social policy? An account and assessment of developments in the Lisbon Social Inclusion Process. Journal of Social Policy, 37(1), 1-19.

Duyulmuş, C.U. 2009. Social security reform in Turkey: different usages of Europe in shaping the national welfare reform. Paper to the RC 19 Conference, 2022 August. [Online]. Available at: http://www.cccg.umontreal.ca/RC19/PDF/ Duyulmus-C_Rc192009.pdf [accessed: 2 August 2011].

European Commission. 2007. Screening Report: Turkey. Chapter 28 -Consumer and Health Protection. [Online]. Available at: http://ec.europa.eu/enlargement/ $\mathrm{pdf} /$ turkey/screening_reports/-screening_report_28_tr_internet_en.pdf [accessed: 9 August 2011].

European Commission. 2009. Commission Decision on a Multi-annual Indicative Planning Document (MIPD) 2009-2011 for Turkey,(2009) 5041. 
European Commission. 2011. Europe 2020: An Agenda for New Skills and Jobs. Luxembourg: Publications Office of the European Union.

European Commission. 2011b. The Measurement of Extreme Poverty in the European Union. Brussels: DG for Employment, Social Affairs and Inclusion. European Commission. 2011c. Regular Report on Turkey's Progress Towards Accession. SEC (2011) 1201. Brussels.

Eurostat. 2010. Persons at risk of poverty after social transfers. [Online] Available at: http://epp.eurostat.ec.europa.eu/tgm/table.do?tab=table\&init=1\&plugin=1 \&language $=$ en\&pcode $=\mathrm{t} 2020 \_52$ [accessed: 15 June 2011].

Frege, C. (2002). Understanding Union effectiveness in Central Eastern Europe: Hungary and Slovenia. European Journal of Industrial Relations, 8(1): 53-76.

Guillén, A. and Alvarez, S. 2004. The EU's impact on the Spanish welfare state: the role of cognitive Europeanisation. Journal of European Social Policy, 14(3), 285-99.

Guillen A., Alvarez, S. and Silva, P.A. 2001. Redesigning the Spanish and Portuguese Welfare States: the Impact of Accession into the European Union. Centre for European Studies Working Paper, No. 65.

Hantrais, L. 1995. Social Policy in the European Union. New York: St. Martin's Press.

Héritier, A. (2005). Europeanization Research East and West: a Comparative Assessment, in The Europeanization of Central and Eastern Europe, edited by F. Schimmelfennig and U. Sedelmeier. Ithaca: Cornell University Press, 199-209. High Level Group. 2004. Facing the Challenge: the Lisbon Strategy for Jobs and Growth. Luxembourg: Office for Publications of the European Communities.

Knill, C. 2001. The Europeanisation of National Administrations. Cambridge: Cambridge University Press.

Ladrech, R. 1994. Europeanisation of domestic politics and institutions: the case of France. Journal of Common Market Studies, 32(1), 69-88.

Larsen, T.P. and Taylor-Gooby, P. 2004. New risks at the EU level: a spillover from open market policies, in New Risks, New Welfare: The transformation of the European Welfare State, edited by P. Taylor-Gooby. Oxford: Oxford University Press, 181-208.

Manning, N. 2007. Turkey, the EU and social policy. Social Policy and Society, 6(4), 491-501.

Mair, P. 2004. The Europeanisation dimension. Journal of European Public Policy, 11(2), 337-48.

Ministry of Health. 2009. Health Transformation Programme in Turkey: Progress Report. MoH Publication No. 749. [Online]. Available at: http://www.saglik. gov.tr/EN/dosya/2-1217/h/-htp2009jan.pdf [accessed: 10 August 2011].

MLSS (Ministry of Labour and Social Security). 2011. 2010 Faaliyet Raporu (2010 Activity Report). [Online]. Available at: http://www.calisma.gov.tr/csgbPortal/ ShowProperty/WLP\%20Repository/tkb/-dosyalar/faaliyetraporu2010 [accessed: 15 August 2011]. 
O'Connor, J.S. 2005. Policy coordination, social indicators and the social-policy agenda in the European Union. Journal of European Social Policy, 15(4), 345-61.

OECD. 2006. Economic Survey: Turkey. Paris: OECD.

OECD. 2009. Society at a Glance: Social Indicators. Paris: OECD.

Page, E.C. 2003. Europeanisation and the persistence of administrative systems, in Governing Europe, edited by J. Howard and A. Menon. Oxford: Oxford University Press, 162-76.

Radaelli, C. 2000. Whither Europeanisation? Concept stretching and substantive change. European Integration Online Papers (EIoP) [Online], 4(8). Available at: http://papers.ssrn.com/sol3/-papers.cfm?abstract_id=302761 [accessed: 15 July 2011].

Radaelli, C. 2003. The Europeanisation of public policy, in The Politics of Europeanisation, edited by K. Featherstone and C. Radaelli. Oxford: Oxford University Press, 27-56.

Radaelli, C. and Schmidt, V. 2004. Policy change and discourse in Europe: conceptual and methodological issues. West European Politics, 27(2), 183210.

Radaelli, C. and Pasquier, R. 2008. Conceptual issues, in Europeanisation: New Research Agendas, edited by P. Graziano and M.P. Vink. New York: Palgrave, 35-45.

Resmi Gazete (Official Gazette). 2008. Sosyal Sigortalar ve Genel Sağllk Sigortasi Kanunu Bazı Kanun Hükmünde Kararnamelerde Değişiklik Yapılmasina Dair Kanun (Decree Law Regarding Changes Introduced to the Social Security and General Health Insurance Law). No: 5754, Say1: 25798, 8 May, Ankara.

Schimmelfennig, F. and Sedelmeier, U. 2005 (eds). The Europeanisation of Central and Eastern Europe. Ithaca: Cornell University Press.

Schimmelfenning F. and Sedelmeier, U. 2008. Candidate countries and conditionality, in Europeanisation: New Research Agendas, edited by P. Graziano and M.P. Vink. Houndmills: Palgrave Macmillan, 88-101.

Teague, P. 2000. EU social policy: institutional design matters. Queen's Papers on Europeanisation, 1.

Threlfall, M. 2007. The social dimension of the European Union. Global Social Policy, 7(3), 271-93.

Tsarouhas, D. 2007. European integration and social policy: from institutionbuilding to policy coordination, in Bridging the Real Divide: Social and Regional Policy in Turkey's Accession Process, edited by D. Tsarouhas, E. Ertugal and A.I. Aybars. Ankara: METU Press, 17-43.

Tsarouhas, D. and Bölükbaşı, T. 2007. Exogenous pressures and social policy: Greece and Turkey in comparative perspective. EUI Working Paper, RSCAS 2007/38.

Tsarouhas, D. 2010. How is the 'European BRIC' faring? Social policy, the labour market and industrial relations in Turkey. South East Europe Review, 13(3), 313-25. 
Tsoukalis, L. 1993. The New European Economy: The Politics and Economics of Integration. Oxford: Oxford University Press.

Turkish Parliament. 2006a. 88. Birleşim Tutanaklari (Minutes of the 88th Parliamentary Session). 22. Dönem (22nd legislative period) Cilt: 116 (Issue: 116), 13 April.

Turkish Parliament. 2006b. 89. Birleşim Tutanaklari (Minutes of the 89th Parliamentary Session). 22. Dönem (22nd legislative period) Cilt: 116 (Issue: 116), 18 April.

Turkish Parliament. 2008. Butce ve Plan Komisyonu Tutanaklari (Minutes of the Budget and Planning Commission). [Online]. Available at: http://www.tbmm. gov.tr/komisyon/planbutce/ssgss/-04_03_2008.htm [accessed: 26 July 2011].

UNDP. 2010. The Real Wealth of Nations: Pathways to Human Development. New York: United Nations Development Programme.

Verbeken, D. 2007. The pension reform challenge in Turkey. ECFIN Country Focus, 4(3), 1-6.

Vink, M.P. and Graziano, P. 2008. Challenges of a new research agenda, in Europeanisation: new research agendas, edited by P. Graziano and M.P. Vink. New York: Palgrave Macmillan, 3-20.

World Bank. (2005). World Development Indicators 2005. Washington DC: World Bank.

World Bank. 2008. Country Partnership Strategy with Turkey, 2008-2011. Report No. 42026-TR. [Online]. Available at: http://www.worldbank.org.tr/WBSITE/ EXTERNAL/COUNTRIES/-ECAEXT/TURKEYEXTN/0,contentMDK:216 78953 pagePK:141137 piPK:141127 theSitePK:361712,00.html [accessed: 11 August 2011].

Yakut-Çakar, B. (2007). Turkey, in Social Policy and International Interventions in South East Europe, edited by B. Deacon and P. Stubbs. Cheltenham: Edward Elgar, 103-29.

Yıldırım, H.H. and Yıldırım, T. 2011. Healthcare financing reform in Turkey: context and salient features. Journal of European Social Policy, 21(2), 178-93.

Y1lmaz,H. andEmil,F.(2010). SocialExpenditureatDifferentLevels of Government: Turkey, Ankara. [Online]. Available at: http://siteresources.worldbank. org/INTTURKEY/Overview/-22827911/socialexpendituresinTurkey.pdf [accessed: 20 October 2011].

Zeitlin, J. and Pochet, P. 2005 (eds). The Open Method of Coordination in Action: The European Employment and Social Inclusion Strategies. Brussels: P.I.E. Peter Lang. 